proposed trajectory, functions of smart flight: Point of Interest and some others. Suggestions for the implementation in investigative and expert practice of unmanned aerial vehicles and scientific and practical recommendations for improving the process of training specialists in using the means, techniques and methods of forensic photo-, videoshooting with unmanned aerial vehicles are formulated.

Keywords: forensic technology, unmanned aerial vehicles, technical and forensic means, photo-, videoshooting of investigative actions, investigative and expert practice.

DOI: 10.33766/2524-0323.89.279-287

УДК 343.98

В. М. Плетенець, кандидат юридичних наук, доцент, доцент кафедри криміналістики, судової медицини та психіатрії Дніпропетровського державного університету внутрішніх справ (м. Дніпро, Україна) e-mail: viktor_plet@i.ua iD https://orcid.org/0000-0002-3619-8624

\title{
МОЖЛИВОСТІ ВИКОРИСТАННЯ ПРОФАЙЛІНГУ В ПОДОЛАННІ ПРОЯВІВ ПРОТИДІЇ РОЗСЛІДУВАННЮ
}

Стаття присвячена висвітленню можливостей використання слідчим профайлінгу для виявлення проявів протидії розслідуванню. Наголошується на поширеності його використання в діяльності правоохоронних органів розвинених країн. Приділяється увага напрямкам профайлінгу та ситуації, що склалась із його застосуванням у діяльності правоохоронщів. Зауважується, що практичне значення профайлінгу полягає в можливості прогнозування вірогідності відповідних проявів для їх попередження та керування ними. Водночас констатується факт епізодичного характеру застосування профайлінгу в практичній діяльності спрівробітників правоохоронних органів, що унеможливлює належний рівень діяльності, у тому числі подолання проявів протидії розслідуванню.

Ключові слова: протидія розслідуванню, профайлінг, прояви емоцій, рішення слідчого.

Постановка проблеми. Незважаючи на суттєвий розвиток техніки та діджиталізацію суспільства, перехід на електронний документообіг, спілкування онлайн, комунікація від цього не перестала бути важливою, а навпаки набуває більшого значення та необхідності правильного використання в діяльності співробітників правоохоронних органів. Усвідомлення того, що доведеться спілкуватися з правопорушниками, котрі можуть характеризуватися високою освіченістю та інтелектом, обумовлює необхідність правоохоронщів підвищувати не тільки свій комунікативний рівень, а й навички виявлення неправдивих свідчень здійсненого з боку зацікавлених осіб, тиску на учасників розслідування.

Цьому може сприяти профайлінг, який набув значного поширення в діяльності правоохоронщів багатьох країн, зокрема Великої Британії, Ізраїлю, Канади, Німеччини, США та інших.

(C) Плетенець В. М., 2020 
Аналіз останніх досліджень і публікацій. Питанням профайлінгу приділяли увагу такі вчені, як: Ю. М. Антонян, О. І. Анфіногенов, В. О. Бакальчук, В. Біркенбіл, А. О. Бухановський, П. Екман, В. А. Лабунська, О. А. Мартиненко, Ф. Олдерт, О. М. Подільчак, В. Селянин, С. Спіріца, О. Фрай, В. Фрізен, М. Цукерман, С. С. Чесакова, К. Шерер, Д. Ющенко та інші.

Водночас можливостям використання профайлінгу в діяльності правоохоронців України взагалі та у виявленні проявів протидії розслідуванню зокрема належної уваги приділено не було, що обумовлює складність оцінки проявів дій відповідних осіб. Несвоєчасне діагностування проявів протидії розслідуванню, значною мірою, впливає на формування несприятливої обстановки, неможливості з'ясування всіх обставин кримінального правопорушення та реалізації визначених КПК України завдань кримінального провадження.

Формулювання цілей. Метою даної статті є висвітлення можливостей використання профайлінгу в подоланні проявів протидії розслідуванню.

Виклад основного матеріалу. 3 огляду на те, що прояви протидії набувають усе білышого поширення, постає питання про необхідність застосування правоохоронщями знань поведінкових елементів, котрі можуть виявлятися в діях учасників розслідування та зацікавлених осіб.

Профайлінг - це поняття, що означає сукупність психологічних методів і методик оцінки та прогнозування поведінки людини на основі аналізу найбілыш інформативних особистісних ознак, характеристик зовнішності, невербальної і вербальної поведінки [1].

Усталеною точкою зору є й та, що профайлінг є практичною реалізацію теоретичних досліджень особи злочинщя, результатом накопичення і узагальнення знань про соціальні, демографічні та психологічні криміногенні особливості осіб, які вчиняють ті чи інші злочини [2, с. 151].

Походження профайлінгу відносять до передпольотного спостереження за поведінкою пасажирів, запровадженого в 70-х роках XX століття. Однак ще Г. Грос, аргументуючи можливості розуміння злочинщя через учинений ним злочин, обгрунтував сутність профайлінгу [3]. Водночас грунтовних наукових розробок у Криміналістичній науці він так і не отримав, однак досить швидко набув свого поширення в інших сферах.

Окрім забезпечення безпеки в цивільній авіації, Д. Ющенко серед напрямків, що є основою профайлінгу, як-от: науково-дослідницький, медико-психологічний, спеціальний, психотехнологічний, - виділяє і криміналістичний [4]. Окремого значення набуває застосування профайлінгу в діяльності співробітників митниць та полімії.

Поліцейський профайлінг розглядають як практику поліції, згідно з якою визначений набір характеристик (профілів) використовується для пошуку та затримання особи, яка вчинила злочин (кримінальний профіль), або для виявлення осіб, які мають відношення до злочинної діяльності (поведінковий профайлінг) [5].

У кримінілогічному контексті профайлінг розглядають як створення психологічного портрету невідомої особи на основі виявлених на місці події (кримінального правопорушення) слідів.

Кримінологічному профайлінгу С. Г. Дзиконська пропонує наступну систематизацію: 
1. Профілактичний - зводиться до встановлення та кримінологічного аналізу інформації щодо осіб з метою ранньої профілактики їх злочинної поведінки, зокрема:

- страховий профайлінг як допомога страховим компаніям у виявленні шахрайських дій під час оформлення страхування;

- профайлінг на транспорті виявляє пасажирів, «які здатні вчинити дебош, які ховають під одягом зброю та інших (особливо виокремлюється авіаційний профайлінг)»;

- готельний профайлінг, який спрямований на профілактику злочинів.

2. Прогностичний (профільне моделювання) - це оцінка мотиваційно-диспозищійної сторони особистості та прогнозування поведінки особи на підставі аналізу найбільш інформативних особистісних ознак.

3. Типологічний - віднесення особи за рядом невербальних ознак до безпечного або небезпечного типу залежно від сощіального оточення й контексту розслідування.

4. Оперативно-розшуковий - складання пошукового психологічного портрету (профілю) невідомої особи за слідами на місці вчинення злочину;

5. Судово-слідчий профайлінг - не інструментальна детекція брехні - оцінка достовірності інформації, що повідомляється людиною за ії невербальною поведінкою; особистості;

- тактичний - побудова слідчої стратегії на підставі побудованого профілю

6. Віктимологичний профайлінг - це складання портрету жертви, або потенщійної жертви [6, с. 95].

Однак наведена класифікація не позбавлена, у першу чергу, термінологічних неточностей. Так стратегія С. Г. Дзиконською включається в тактику. Обидві зазначені категорії широко використовуються в багатьох галузях знань, проте мають військове походження.

«Стратегія - мистецтво підготовки та ведення війни та великих воєнних операцій // наука про систему гри в спорті, за якої окремі ходи, комбінації, прийоми підпорядковано загальному, раніше обміркованому плану» [7, с. 1399].

Тактика з часів Плутарха вважалась вінцем військового мистецтва [8].

Своєю чергою, Г. Жомини визначає стратегію як мистецтво вести війну за картою, мистецтво охопити увесь театр війни. Тактика, на думку автора, це мистецтво битися на місцевості, розташовувати сили відповідно до місцевих умов та вводити їх у бій на різних пунктах поля бою [9, с. 109].

Не вдаючись у поглиблений аналіз, можемо зрозуміти, що тактика і стратегія хоч і споріднені й нерозривні категорії, однак не є тотожними та мають відмінності в масштабі діяльності. Сама по собі стратегія не може існувати без визначення конкретних дій та заходів їі реалізації, які виступатимуть тактикою. Тобто наведене визначає тактику як складову стратегії.

Тому, на нашу думку, С. Г. Дзиконській доречніше було б казати про стратегію, у рамках якої, на підставі побудованого профілю особистості, розроблялася б слідча тактика.

Окрім того, остання є розділом науки «Криміналістика», тому коректність ï включення як складової кримінологічного профайлінгу також викликає питання. 
Незважаючи на те, що думки вчених розходяться в належності профайлінгу, вважаємо, що він має значний потенщіал застосування, зокрема й у криміналістищі. Прилаштування профайлінгу можливе для підвищення рівня застосування знань криміналістичної тактики, організації та планування розслідування, проведення окремих слідчих (розшукових) дій тощо. Певного значення, на нашу думку, потребує дослідження можливостей використання профайлінгу в діагностуванні провів протидії розслідуванню.

На сьогодні тільки людина $з$ певною долею вірогідності спроможна до зчитування внутрішньої інформації, визначення особливостей та динаміки поведінки інших людей та до оперативного прийняття рішень [10].

Навчитися правоохоронщям зазначеному є не тільки можливим, а й необхідним у сучасних умовах боротьби зі злочинністю. Однак лише 33 \% проінтервйованих слідчих вказують на застосування профайлінгу у своїй діяльності. Це, на нашу думку, демонструє неналежне ставлення та, відповідно, рівень його застосування правоохоронщями, що не сприяє покращенню їхньої діяльності.

Неправдива інформація має доволі широкий синонімічний ряд: брехня (контрарний антонім до «правда»), обман, кривда, ошука, фальш, вигадка, наклеп, байка та ін. [11, с. 32]. Та які б синоніми не використовувалися для трактування неправдивих показань відповідних учасників, вони є доволі поширеним явищем у діяльності правоохоронщів, а їх виявлення - запорукою встановлення об'єктивної картини події вчиненого кримінального правопорушення.

Для того щоб виявити брехню, необхідно шукати невідповідності між змістом і невербальними засобами вираження повідомлення [12].

Однак, перш ніж виявляти протиріччя, слідчий має ввести особу в спілкування, створити сприятливу атмосферу, встановити психологічний контакт, визначити загальний рівень розвитку, здатність співрозмовника адекватно оцінювати обстановку, реагувати на їі зміни. Нейтральні теми дозволяють виявити реакції співрозмовника, ступінь емоційності, його готовність до діалогу тощо.

Зазначене має стати відправною точкою в аналізі отримуваних при подальшому спілкуванні відомостей на предмет неповноти та недоставірності. Зокрема, коли слідчий торкатиметься так би мовити «незручних» питань (тобто тих, котрі особа не бажає, унаслідок певних причин, висвітлювати), порівнюючи реакції та емоції особи при спілкуванні на нейтральні теми, можуть виявлятися зміни в іiі поведінщі. Їх аналіз сприятиме обгрунтованим припущенням про переслідувані цілі та мотиви, котрими керується відповідна особа, причини зайнятої позищії, визначення шляхів впливу на неї, найбільш доцільну лінію поведінки, доречність застосування відповідних тактичних прийомів тощо.

Якщо основу конщепщії профайлінгу «накласти» на процес розслідування, отримаємо положення про те, що причетність до факту протидії розслідуванню відповідних учасників можемо виявлятися за проявами їхніх емоцій.

Факти протидії розслідуванню, за більшістю кримінальних проваджень, обумовлюють необіхність вжиття для їх виявлення будь-яких заходів та засобів, у тому числі й профайлінгу. Зокрема, недобросовісна позиція певного учасника може бути пояснена застосованим по відношенню до нього тиском із боку зацікавлених осіб. Однак через об'єктивні та суб'єктивні чинники, своєчасне виявлення зазначених проявів не відбувається, що унеможливлює їх оцінку, у тому числі й правову. 
Окрім виявлення фактів тиску, практичне значення профайлінгу полягає в прогнозуванні вірогідності відповідного прояву з метою їх упередження. Усвідомлення того, що особа може стати об'єктом тиску з боку зацікавлених осіб, слідчому необхідно прийняти дієві організаційно-тактичні заходи, спрямовані на його недопущення.

Відомості про відповідного учасника можуть отримуватися шляхом аналізу кримінальних проваджень, баз даних, характеризуючого матеріалу, соціально демографічних відомостей, мотивів можливих дій тощо. Це сприятиме формуванню припущень про вірогідні способи здійснення протидії розслідуванню.

У системі профайлінгу значний інтерес викликають особливості поведінкових реакцій відповідних учасників розслідування. Виявлення реакщії особи на відповідний подразник визначає необхідність встановлення її причини. Серед можливих пояснень, варто розглядати таке: володіння інформацією про подію та спроби іiі приховати; особа не має відношення до події, однак емоційно реагує на те, що відбувається.

Так виявлення у спілкуванні з особою невластивої поведінки, відстороненості, награності, показовості, варто розглядати важливим проявом загальної неадекватності психологічного стану. Причина перебування у відповідному стані може бути перевірена шляхом зосередження уваги на певних темах, зокрема на зміні свідчень, формуванні уявлення про непоінформованість, неможливість зрозуміти вимоги, що ставляться до особи.

Зміна поведінки (спостереження страху, тривоги, напруженості), зазвичай відбувається під час зачіпання відповідних тем, що є проявом, котрий може бути зчитано, у першу чергу, з обличчя.

Емоції виступають, приміром, як індикатор трудності чи оцінка значущості ситуації для особи; або чинник, що призводить до зміни поведінки в ситуащії. Емоційні переживання є найважливішим компонентом адаптивної поведінки людини у складній ситуації [13, с. 198]. Прояви емоції можуть бути використані слідчим у розслідуванні кримінального правопорушення та діагностуванні можливої участі в здійсненні відповідним учасником тиску, протидії або того, що якийсь учасник став його жертвою.

На основі аналізу рухів м'язів обличчя компанія Paul Ekman Group навіть розробила Систему кодування рухів обличчя (The Facial Action Coding System (FACS)) [14].

Реакції на переживання можуть проявлятися у вигляді жестів, міміки, позах, збільшеного потовиділення, збліднення або почервоніння шкіри і т. інш. Однак навчена контролювати прояви своїх емоцій особа може не настільки яскраво їх проявляти. У результаті цього спостерігач, імовірно, і не помітить проявів емоцій або неправильно їх інтерпретуватиме i, таким чином, може бути введений в оману.

Білышість співробітників поліції, діяльність яких повязана зі спілкуванням, здобувають практичні навички отримання вагомої інформащії за зовнішніми проявами реакцій та емоцій відповідної особи. Зокрема, у випадку зупинки наркомана, який у спілкуванні виявляє показну, зазвичай, не властиву йому люб’язність, сприймається співробітниками оперативних підрозділів, як маркер, що вказує на наявність у даної особи при собі наркотичних засобів (психотропних речовин, прекурсорів). ІНші особи, навпаки, використовуючи прояви агресії, намагаються подолати в правоохоронщів бажання здійснювати зовнішню перевірку. 
Обидва зазначені прояви варто оцінювати як захисну реакцію, спрямовану на уникнення викриття.

Підозріла поведінка, коли особа, побачивши співробітників поліції, змінила траєкторію свого руху (розвернулася, пішла в іншу сторону, перейшла на протилежний бік вулищі, забарилася), визначається співробітниками патрульної поліції та дільничними проявами, котрі можуть вказувати на вчинення особою правопорушення.

Зазначене варто оцінювати проявом інстинкту самозбереження, спробою дистанщіюватися, що реалізується в намаганні уникнути небажаного контакту та можливого викриття в причетності до правопорушення.

Наведені приклади вказують на те, що за відсутності правильної інтерпретації поведінки зазначенх осіб з боку співробітників правоохоронних органів звужуються можливості їхньої діяльності. Водночас для більшості суддів зазначені прояви не $є$ аргументом для здійснення, наприклад, зовнішньої перевірки особи та виявлення заборонених до обігу предметів, про що наголосили всі проінтервйовані співробітники оперативних підрозділів, патрульної поліції та дільничні офіцери поліції. Це, своєю чергою, може поставити під сумнів законність виявлених в особи об'єктів.

Фактично відбувається ситуація, коли недостатнє усвідомлення можливостей профайлінгу особами, котрі приймають рішення за відповідними, наприклад, адміністративними протоколами, ставлять під сумнів те, що в більшості розвинених країн $є$ практикою.

Через те знання профайлінгу не тільки не заохочуються, а й піддаються сумніву щодо його можливості, що ще більше переводить їх у розряд епізодично використовуваних.

Зазначене повною мірою відображає реалії використання профайлінгу та, як наслідок, недостаньої продуктивності діяльності правоохоронщів.

Висновки. Отже, використання профайлінгу в практичній діяльності спрівробітників правоохоронних органів носить епізодичний характер, що унеможливлює належний рівень діяльності, у тому числі подолання проявів протидії розслідуванню.

Зміна ситуації на краще нам вбачається в застосуванні як міжнародного, так і вітчизняного досвіду профайлінгу в діяльності правоохоронних органів взагалі та слідчих підрозділів зокрема.

Своєчасна та правильна інтерпретація проявів поведінки відповідних учасників забезпечить правоохоронців інформацією для оцінки їхніх дій. Правильне трактування правоохоронщями виявлених маркерів є запорукою прийняття обгрунтованих рішень. Прояви емоцій можуть бути використані слідчим у розслідуванні кримінального правопорушення та при діагностуванні застосованого відповідним учасником тиску, а також того, що якийсь учасник став його жертвою.

Сподіваємося, наші подальші дослідження спрямовуватимуться на приділення уваги семіотиці - науці про знаки та знакові системи.

\section{Використані джерела:}

1. The Compact Edition of the Oxford English Dictionary / English Dictionary. New York: Oxford University Press, 1971.1616 p. 
2. Подільчак О. М. Криміналістичний профайлінг - реалізація вчення про особу злочинщя. Право і суспільство. 2017. № 4. Частина 2. С. 148

3. Gross. H. Criminal Investigation. L. 1924.

4. Ющенко Дмитрий. Современный профайлинг. Менталист на страже наших интересов. URL: https://www.b17.ru/article/30624/

5. Ethnic profiling in the European Union: Pervasive, Ineffective, and Discriminatory. Published by Open Society Institute, New York, 2009.

6. Дзиконская, С. Г. Криминологический профайлинг: понятия и виды // Актуальные проблемы гуманитарных и естественных наук. 2015. № 4. С. 93-95.

7. Великий тлумачний словник сучасної української мови (з дод. і допов.) / Уклад. i голов. ред.. В. Т. Бусел. К.; Ірпінь: ВТФ «Перун, 2005. 1728 с.

8. Плутарх. Сочинения URL: https:// books.google.com.ua/books?id

9. Жомини Г. Стратегия и тактика в военном искусстве URL: https:// www. litmir. $\mathrm{me} / \mathrm{br} / \mathrm{b}=193225$

10. Цветков В. Л. Профайлинг в деятельности органов внутренних дел. М.: ЮнитиДана: Закон и право, 2014.

11. Психологический словарь / под ред. А. В. Петровского, М. Г. Ярошевского. - [2-е изд., испр. и доп.]. М.: Политиздат, 1990. 494 с.

12. Экман П. Узнай лжеца по выражению лица / П. Экман, У. Фризен; пер. с англ. В. Кузина. СПб.: Питер, 2010.336 с.

13. Анщупов А. Я., Шипилов А. И. Конфликтология: Учебник для вузов. М.: ЮНИТИ, 2000.551 c.

14. The Paul Ekman Group is now offering FACS. Facial Action Coding System. URL: http://www.paulekman.com/product-category/facs/.

\section{References:}

1. The Compact Edition of the Oxford English Dictionary (1971). English Dictionary. New York: Oxford University Press. [in English].

2. Podil'chak O. M. (2017) Kryminalistychnyj profajling - realizacija vchennja pro osobu zlochyncja -Forensic profiling is the realization of the doctrine of the offender. Pravo i suspil'stvo Law and Society, 4, part. 2, 148. [in Ukrainian].

3. Gross, H. (1924) Criminal Investigation. L. [in English].

4. Jushhenko Dmitrij. Sovremennyj profajling. Mentalist na strazhe nashih interesov-Modern profiling. The mentalist on guard of our interests. URL: https://www.b17.ru/article/30624/. [in Russian].

5. Ethnic profiling in the European Union: Pervasive, Ineffective, and Discriminatory. (2009) Published by Open Society Institute, New York. [in English].

6. Dzikonskaja, S. G. (2015). Kriminologicheskij profajling: ponjatija i vidy Aktual'nye problemy gumanitarnyh i estestvennyh nauk - Actual problems of the humanities and natural sciences, 4, 93-95. [in Russian].

7. Busel, V. T. (Eds.). (2005) Velykyj tlumachnyj slovnyk suchasnoi' ukrai'ns'koi' movy(z dod. i dopov.). Kyiv: Irpin: VTF «Perun». [in Ukrainian].

8. Plutarh . Sochinenija. N. d. N. p. URL:https:/ / books.google.com.ua/books?id

9. Zhomini, G. Strategija i taktika v voennom iskusstve. N. p. URL: https:// www. litmir. $\mathrm{me} / \mathrm{br} / \mathrm{b}=193225$ [in Russian].

10. Cvetkov, V. L. (2014) Profajling v dejatel'nosti organov vnutrennih del. Moskva:«JunitiDana»: Zakon i pravo. [in Russian].

11. Petrovskii A. V., \& Jaroshevsko M. G. (1990). Psihologicheskij slovar' (Vol.1-2; Vol.2, ispr. i dop.). Moskva: «Politizdat». [in Russian]. 
12. Jekman P. (2010). Uznaj lz eca po vyrazheniju lica. P. Ekman, U. Fryzen (Eds.);V. Kuzyn et. al.SPb.: «Piter». [in Russian].

13. Ancupov A. Ja., \& Shipilov A. I. (2000). Konfliktologija. Moskva:«JuNITI» [in Russian].

14. The Paul Ekman Group is now offering FACS. Facial Action Coding System. N. d. N. p. URL: http://www.paulekman.com/product-category/facs/. [in English].

Стаття надіӥшла до редколегії 18.02.2020

Плетенец В. Н., кандидат юридических наук, доцент, доцент кафедры криминалистики, судебной медищины и психиатрии Днепропетровского государственного университета внутренних дел (г. Днепр, Украина)

\section{ВОЗМОЖНОСТИ ИСПОЛЬЗОВАНИЯ ПРОФАЙЛИНГА В ПРЕОДОЛЕНИИ ПРОЯВЛЕНИЙ ПРОТИВОДЕЙСТВИЯ РАССЛЕДОВАНИЮ}

Статья посвящена освещению возможностей использования следователем профайлинга в выявлении проявлений противодействия расследованию. Отмечается распространенность его использования в деятельности правоохранительньх органов развитьх стран. Уделяется внимание направлениям профайлинга и самой ситуации, которая сложилась с его использованием в деятельности сотрудников правоохранительных органов. Подчеркивается, что практическое значение профайлинга заключается в возможности прогнозирования вероятности соответствующих проявлений для их предупреждения и управления. В то же время констатируется факт эпизодического характера использования профайлинга в практической деятельности сотрудников правоохранительных органов, что делает невозможным надлежащий уровень деятельности, в том числе и преодоления противодействия расследованию.

Ключевые слова: противодействие расследованию, профайлинг, проявления эмоций, решения следователя.

PletenetsV.,

Candidate of Law, Associate Professor, Associate professor of the Department of criminalistics, forensic medicine and psychiatry of Dnepropetrovsk State University of Internal Affairs

(Dnipro, Ukraine)

\section{POSSIBILITIES OF USING PROFILING IN OVERCOMING THE MANIFESTATIONS OF RESISTANCE TO INVESTIGATION}

The article is devoted to highlighting the possibilities of the investigator using profiling to identify signs of resistance to investigation. It is widely used in law enforcement, in particular by customs and police officers in the developed world. 
In the criminological context, profiling is viewed as the creation of a psychological profile of an unknown person, based on traces found at the scene of the incident (a criminal offence).

Although scientists differ on the subject of profiling, it has considerable potential for use, including forensic science. Profiling can be used to improve the use of forensic tactics, the organization and planning of investigations, the conduct of individual investigative (search) actions, and so on.

The above-mentioned results of the interviews with the officers of the investigative units reveal a lack of application, which does not help to improve their work.

It is noted that if the basis of the profiling concept is "superimposed" on the investigation process, it is possible to obtain a provision that the reactions of the participants concerned will be detected on the basis of their emotions. However, due to objective and subjective factors, these manifestations are not detected in a timely manner, which makes it impossible to assess them, including legal ones. Based on the analysis of the situation, it is determined that profiling knowledge is not only not encouraged, but also questioned. In this way, what is practised in most developed countries becomes even more ad hoc.

In addition to detecting pressure, the practical value of profiling is that it is possible to predict the probability of occurrence and can be used to pre-empt unlawful acts. It is noted that emotions act as: an indicator of difficulty; an assessment of the significance of the situation for the person; a factor that changes the behaviour of the situation. A change in behaviour (fear, anxiety, tension) usually occurs when the relevant subjects are touched, which can be indicative. In this case, information may be taken from the person concerned.

The fact that the investigator ascertains the involvement of the relevant investigator (an outsider) in the counteraction necessitates the adoption of appropriate organizational and tactical decisions on the conduct of the investigation and individual investigative (search) actions. That is, the investigator, feeling the pressure, can understand, the course of action, and the motivation of the person concerned and thus make more informed decisions, overcome the resistance. The decision to do so, in each case, involves a thorough investigation and a comprehensive approach to the proceedings under investigation.

The findings point out. A change in the situation can be seen in the application of both international and domestic profiling experience in the activities of law enforcement agencies in general and investigative units in particular.

Keywords: resisting investigation, profiling, displaying emotions, investigating officer's decision.

DOI: 10.33766/2524-0323.89.287-297

УДК 343.34

М. О. Семенишин, кандидат юридичних наук, докторант Донецького юридичного інституту МВС України (м. Кривий Ріг, Україна) e-mail: gupolice@dn.npu.gov.ua iDhttps://orcid.org/0000-0002-4892-2843

\section{ОКРЕМІ ПРОБЛЕМИ КРИМІНАЛЬНОЇ ВІДПОВІДАЛЬНОСТІ ЗА ЗЛОЧИНИ, ПОВ'ЯЗАНІ 3 ТЕРОРИСТИЧНОЮ ДІЯЛЬНІСТЮ}

У статті, за матеріалами операції Об'єднаних сил, виокремлені головні проблеми кримінальної відповідальності за злочини, пов'язані з терористичною діяльністю. На підставі аналізу правових норм Кримінального кодексу України, що стосуються терористичної діяльності та їх практичного застосування під час досудового слідства встановлено,

(C) Семинишин M.O, 2020 